\title{
リグニンスルフォン酸溶出量測定に依る
}

\section{S.P. 蒸解の管理に就て}

\section{（S.P. 蒸解終點帅定の新方法）}

\section{I 緒言}

悪硫酸法蒸解に於て，乙の終點の牛定は，蒸解及び パルプ品質の管理上極めて重要な閏題である。從本こ の管理方法として一般に行われているのば, 比色法, 殘酸濃度測定及ひ廃液の比重測定等ごもり，特に比色 法は簡伐である䉆廣く實用化されている。然し何れの 方法に依つても正確な結果は期し難い政は衆知である。 要するに未炕蒸解の進行度を迅速且つ正確に數值で表 示する方法がなく，蒸解手の經驗と勘に依存する棸が 多からた。

然るに先般九大，千手諒一博土により，グリエール キトーザンを沈澱邶とする蒸解廃液中のリグニンスル フォン酸の迅速新定量法が登見されて，この方法の S.P. 蒸解終默沃定に対する遥應性が示唆された。（倘, 本法に関聯するリグニン新定量法の工場宣驗報告は既 に高千穂製紙に依り登されている。)

即ち西硫酸法蒸解に於ては主として木材中のりグ二 ンをスルフォン化して水溶性とし，これを溶解除去し

\section{十條製紙株式會匫八代工場}

て繊維を残す所謂脫リグニン反應であるから蒸解の進 行に件ない蒸解液中のリグニンズルフォン酸量は漸墳 する。從つてリグニンズルフォン酸溶山量は蒸解進行 度を示す尺度となる譯である。故に溶解終點に於ける 庣液のリグニンズルフォン酸溶出量とバルプの蒸解度 その關係を求めて置けば, 希望する蒸解度のバルプを 得る篇には廢液のリグニンズルフォン酸量がその蒸解 度に對應する點佳した時を以て蒸解の終點とすれば 良いことになる。

本報は主としてこの新方法を當工場に適用する䉆に

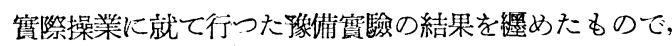
適用後の蒸解度の變動範湋等をも包含した。

\section{II 實 驗の 概 要}

1. 目的及び方針

蒸解進行過程に於て蒸解液中の!グニンズルフォン 酸量（以下 L.S. 量と略す）が如何なる經過によつて 增加するかを見ること，並びにイージー文びストロン グ蒸解の從來行われて來た方法による蒸解終點に於け

第1四L.S 溶出曲缐

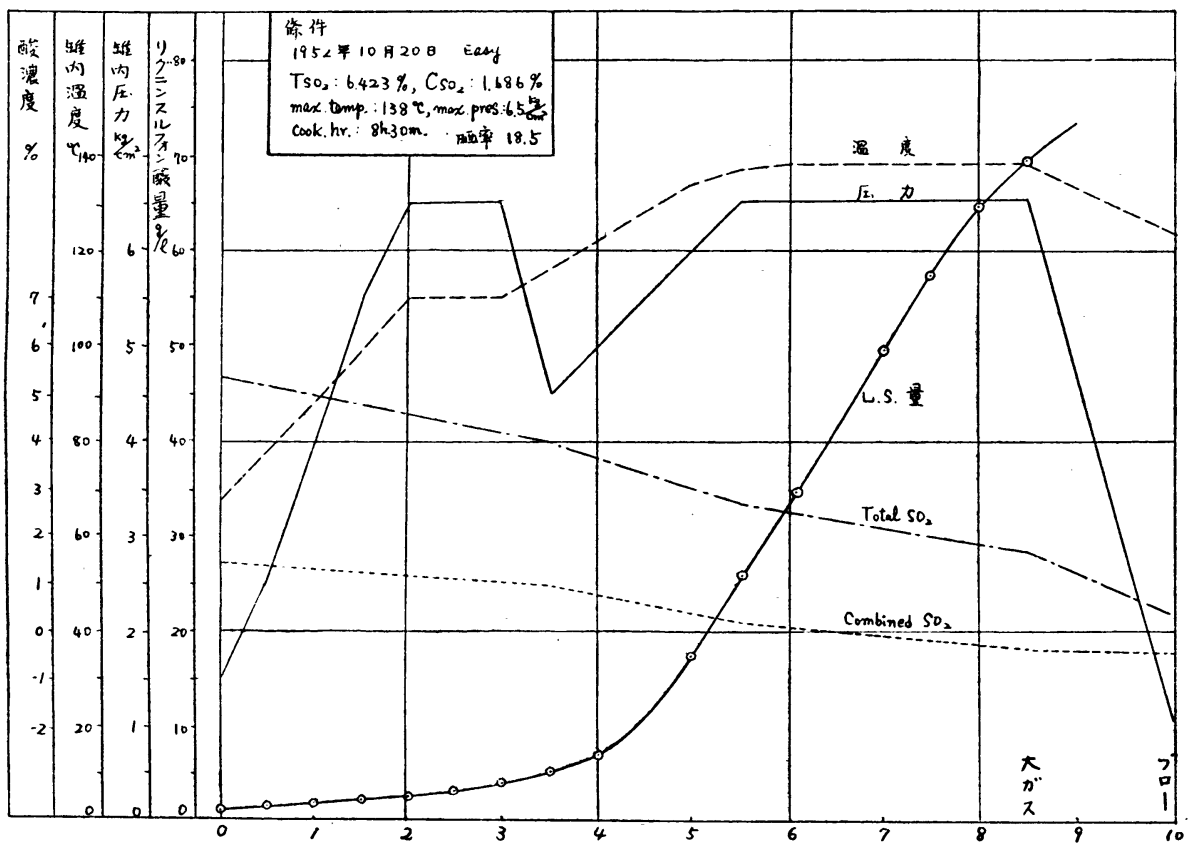

菒苦 月 $\mathrm{hr}$. 


\section{第2回至解末期・L.S. 楁出由缐}

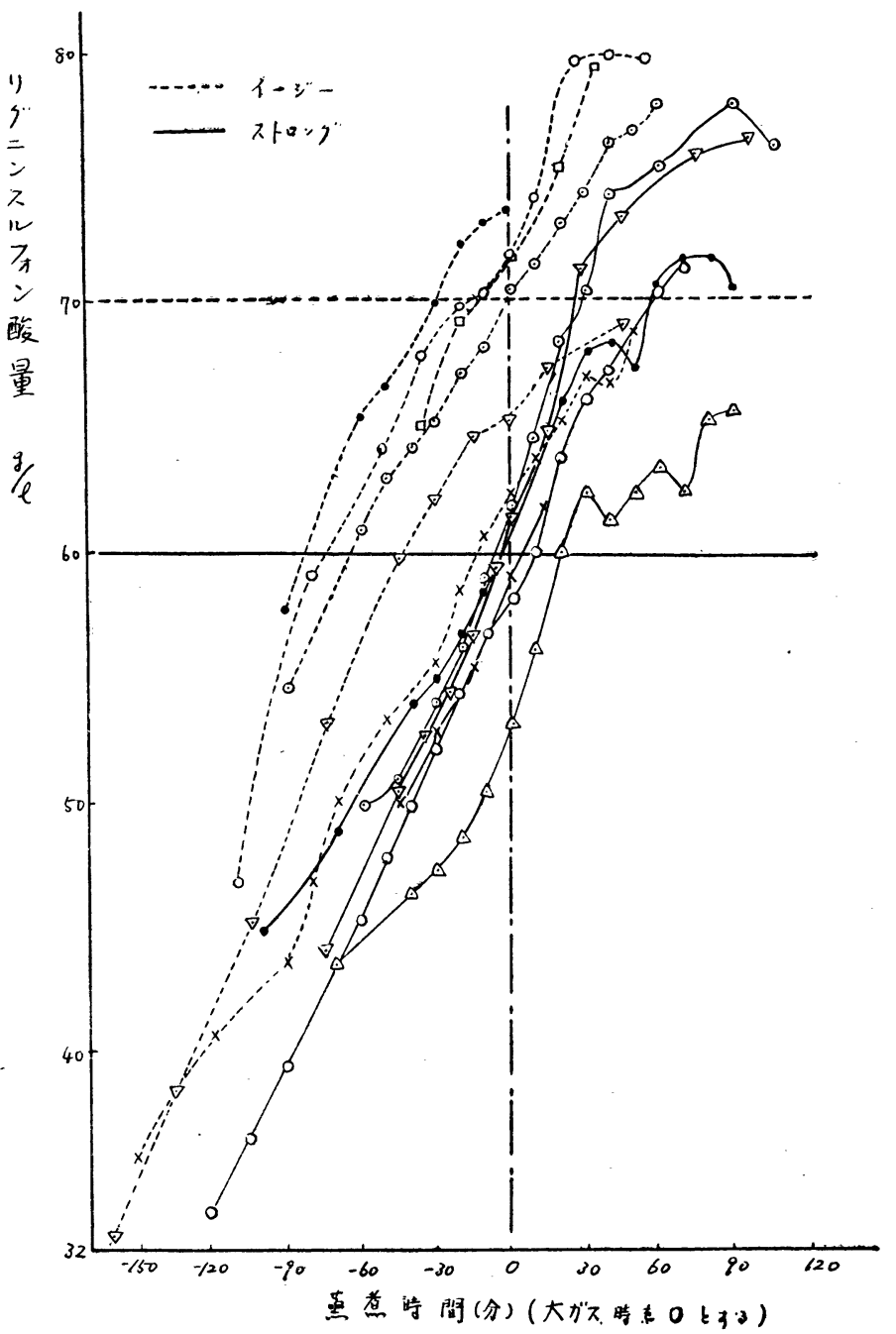

\section{3. 試料探取}

試料として當工場 3 本の木釜より大ガ ズ開始時の蒸解廢液をイージー蒸解の場 合 73 釜分, ストロング蒸解の場合 56 金 分をそれどれ約 $100 \mathrm{cc}$ 宛探取した。又 別個に 20 金分は蒸解開始より 適當な時 間間隔を以て蒸解液及び廢液を探取し た。

\section{4. 蒸解度測定}

各金のパルプ試料としてブローピット 內の一定個所加蒸解原質約 $200 \mathrm{~g}$ を採 取して未蒸解物を節別後洗條し，イージ ーパルプは常法により唒率を測定，スト ロングパルプは Tappi Standard に從つ て過マンガン酸カリ價を求めたる後監素 價 (Chlorine No.) に換算して表示した。

\section{II 䆩驗結果及び考察}

1. イージーパルプの正規蒸解に打け る L.S. 溶出狀況

第 1 圖はイージー蒸解の進行過程にお ける代表的 L. S. 溶出量の狀沉を示する のである。

この結果より考察すれば蠸內溫度 $110^{\circ} \mathrm{C}$ 迄 ( 2 番通汽以前) では L.S. 量 の溶出は極めて少く $(1 \sim 2 \mathbf{g} / 1 / \mathrm{hr})$, 從 つて蒸解の進行は非常に緩慢でもること を示している。これは蒸解の初期に特い ては專ら藥液のチップ內への浸透及びッ グニンの固相反應が行われるといら Hägglund の說を或る程度立證するるの である。

罐內溫度 $120^{\circ} \mathrm{C}$ 附近 (2 番通汽後 1 時

る L.S. 量と蒸解度との關係を求め, 希案する蒸解度 のパルプを得るに必要な蒸解終點沃定の基礎を雄立寸 ることに主眼を置いた。

蒸解終點の決定は結局希望する蒸獬度のバルプを得 る篇にはどの默で蒸解を止めれば良いかを沃定するこ とであるから, 大部分の場合は大ガズ開始時の蒸解廢 液を試料として L.S. 量を測定し, 各蒸解每の L.S 量 とバルプ蒸解度との關係を求めて檢討することにした。 2. L.S. 量定量法

方法の概略を述べれげ次の如くである。 正確に 20 倍に稀釋した蒸解廢液 $5 \mathrm{cc}$ に $\frac{\mathrm{N}}{100}$ グリコ ールキトーザン（以下 G.Ch と略す）の既知量通常 $5 \mathrm{cc}$ を加穴噔液中の L.S. を完全に沈澱せしめたる後, 殘餘の G.Chを $\frac{\mathrm{N}}{400}$ ポリビニールアルコール硫酸工 ステル (以下 P.V.A.S. そ略す) で逆滴定して G.Ch. の消費量を求め，これより廢液中の L.S. 量を算出寸 る。
間）より L. S. 量の溶出は漸增して $5 〜 10 \mathrm{~g} \mathrm{I} / \mathrm{hr}$ とな り, 最高溫度 $138^{\circ} \mathrm{C}$ 到澾の前後が最も蒸解進行度が 急激で 15〜18 g/1/hr を示し, 蒸解末期では 10〜15 $\mathrm{g} / 1 / \mathrm{hr}$ でやや䌅慢になる。大ガズ開始後も L. S. 溶出 量は增加を示し溶出曲線に變動を起すが(第 2 圖參照), これは循環ポンプの運轉を既に停止して居るので部分 的な液の不均一を生じ，これが大ガズの振動に依つて

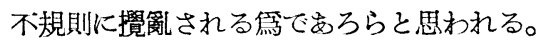

2. $100^{\circ} \mathrm{C}$ 止女釜の場合の L.S. 溶出狀況 $100^{\circ} \mathrm{C}$ 止め釜とは第 1 通汽後休日にかかる場合に 20 〜 $24 \mathrm{hrs} 100^{\circ} \mathrm{C}$ を維持し柆日 2 番通汽を行つて蒸解を 行う場合で, この㭙の蒸解終點の制定が從來困難であ つた。

第 3 圖は代表的な2つの例炕就いて L.S. 溶出狀況 を正規蒸解の場合と比較して示したものである。

第 3 圖より明かな如 $<, 2$ 番通汽開始迄の $100^{\circ} \mathrm{C}$ 維 持期間中は L.S. 溶出量は殆んで直線的に增加し約 1.5 
第3国 $100^{\circ} \mathrm{C}$ 止, 釜L.S 溶出曲缐

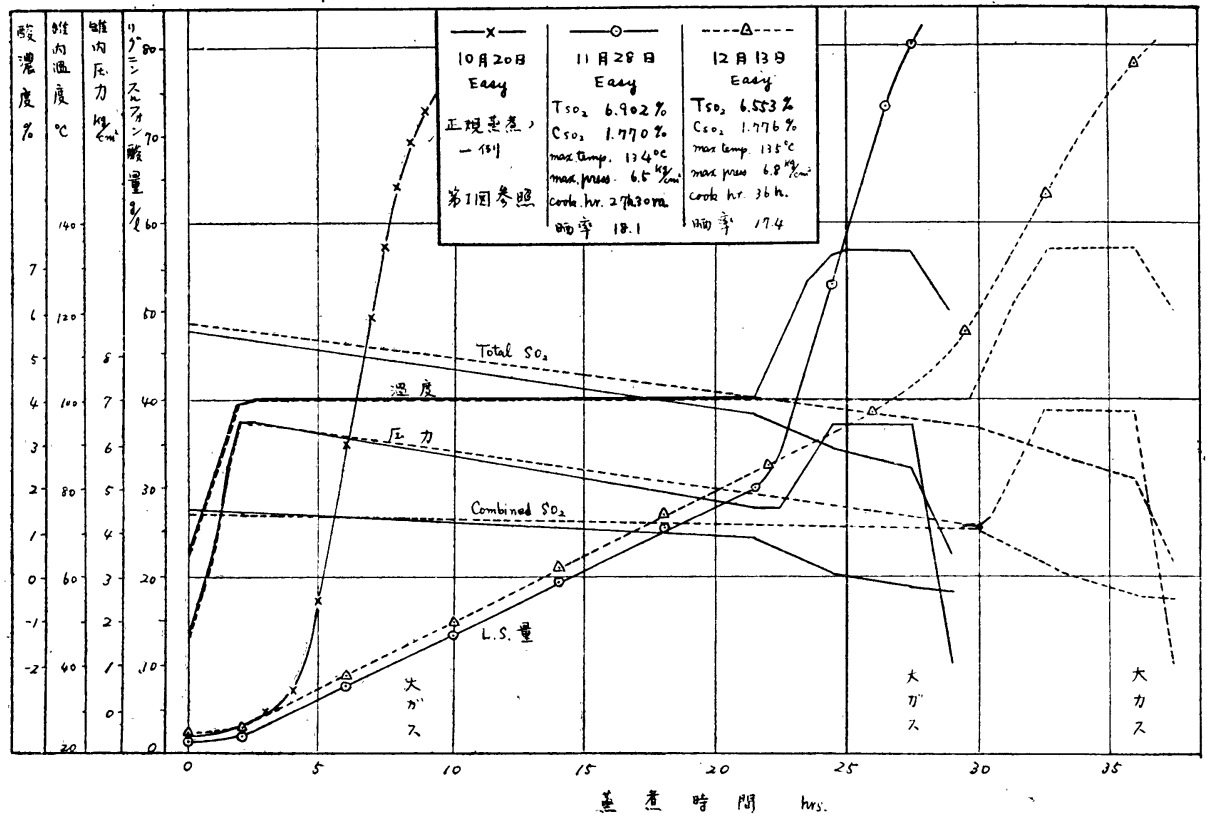

第4四要触度〜L.S 溶出量(イーシ一)

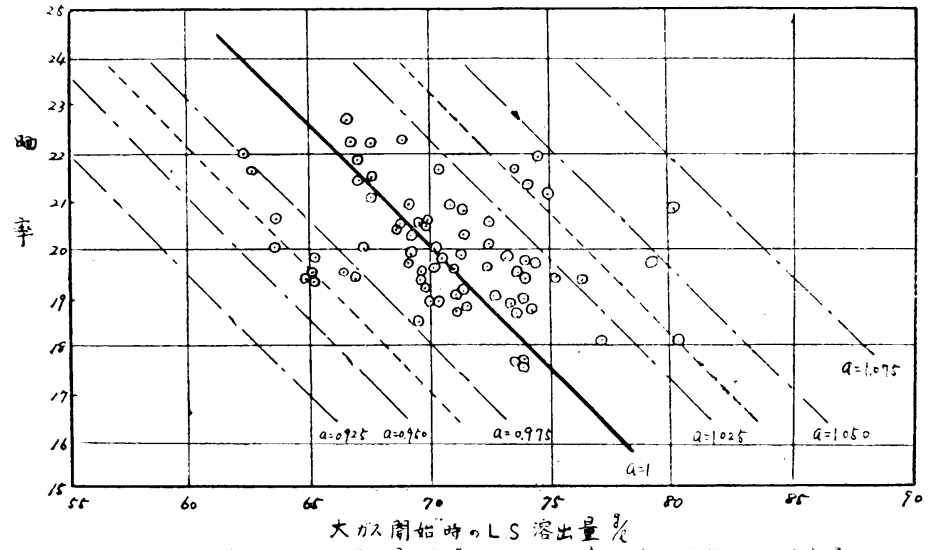

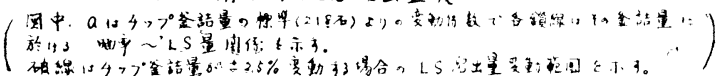

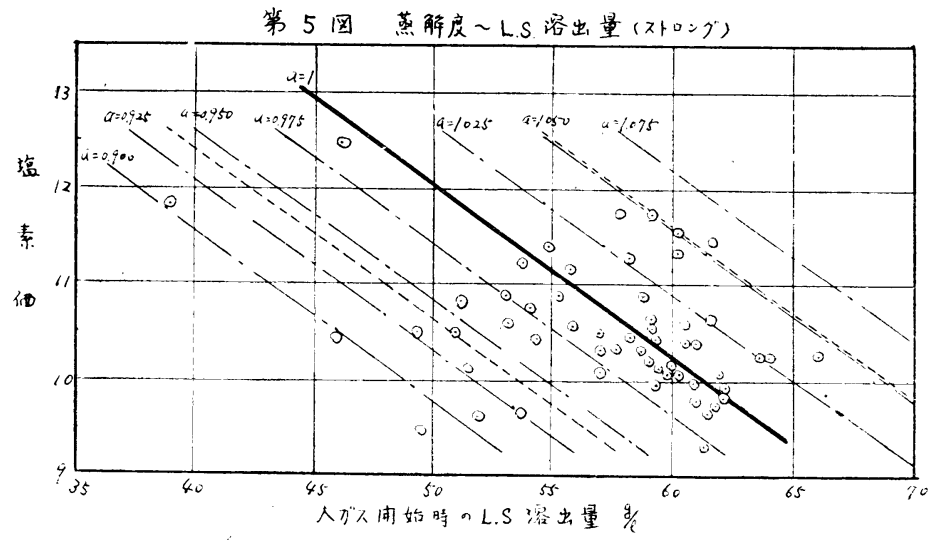

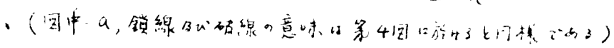


牙6圆大ガス時LS溶出量ヒストブラム

(ストロング)

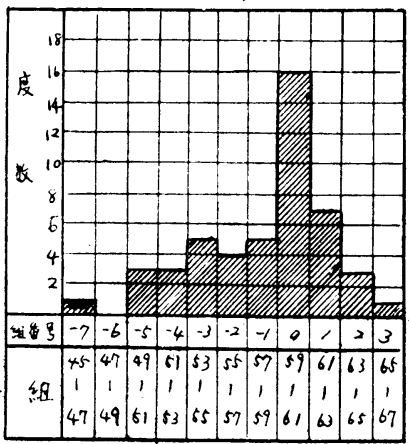

$\left(1-2^{-}\right)$

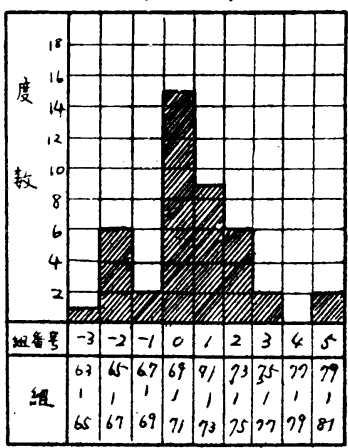

g $1 / \mathrm{hr}$ である。これを正規蒸解の場合 と比較すれば, $100^{\circ} \mathrm{C}$ 維持 20 時間では 正規蒸解 ( 8 時間 30 分) の場合の 5 時 30 分間程度, 又 28 時間では 6 時閒 30 分程度に相當する蒸解進行度を示す。 從つて 2 番通汽以後を通常の蒸解工程 に從つて行えば當然過蒸解となり，從

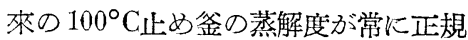
蒸解の場合より唒率にして $2 \sim 3 \%$ 低 かつた事が解明された。

從つてこれが對策としては現在より 大ガズ開始を早くし最高溫度保持を $1 *$

*〜2時間短縮するか，又は最高溫度を低下するか，或 いは休日中の維持溫度を低くするか，が考えられる。 現在當工場では第 3 者の方法師ち維持溫度を $90^{\circ} \mathrm{C}$ に 下げて操業を行つている。

3. 大ガズ開始時の L.S. 溶出量とバルプ蒸解度 との關係

第 4 圖及び第 5 圖はそれぞれイージー及びズトロン グ蒸解に括ける大ガフ開始時の廢液中の L.S. 量と蒸
解パルプの唒萃及び監素價との關係を示するのでまる。 この結果を基礎にして更に蒸解度の許容變動範圍內

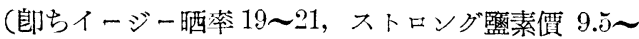
11.0）に得られた釜の L.S. 溶出量に就いてそのとスト グラムを畫けば兩者共第 6 圖に示す如き正常な頻度 分布が得られ更。この結果より明らかな如くイージー の場合リグニン溶仙量 $69 \sim 71 \mathrm{~g} / \mathrm{l}$ ，ストロングの場合 は 69〜61 g/l の組がそれぞれ最も頻度が高い。郎ち

第 1 表

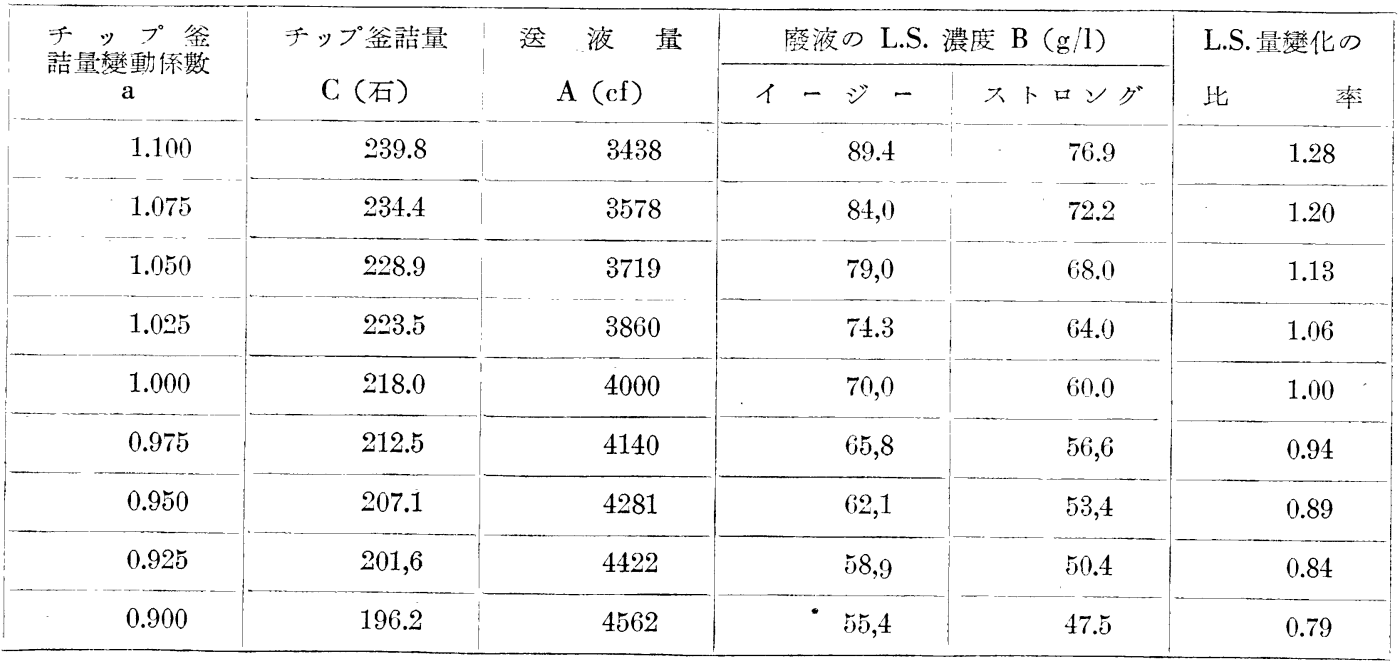

標淮操業の場合に希望する蒸解度のパルプを得んとす れば大ガス開始時の廢液中の L.S. 溶出重はイージー 及びストロング蒸解の場合にそれぞれ $70 \mathrm{~g} / 1$ 及び 60 $\mathrm{g} / 1$ と見なして差支えない。この標準 L.S. 溶出量を 中心にして左在へのばらつきがあるのはチップ釜詰量, 材質等の變化によると見られる。 L.S. 溶出量の變化 に件ら蒸解度の變動はイージー，ストロングでそれぞ

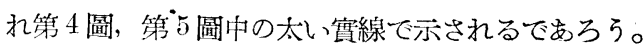

4. L.S.S. 溶出量に及ぼすチップ金詰量變化の影響 元來蒸解の進行に件弓液中の L.S. 濃度は, 樹種, 材質, 金詰量, チップ水分, 送液量及び回收量の變化 によつて當然變陲すべきものでもる。

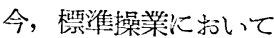

$L$ ： 大ガス開炲時の廢液中の L.S. 量 $(\mathrm{kg})$

$C w:$ チップ水分量 $\left(\mathrm{m}^{3}\right)$

$A$ ：送液量 $\left(\mathrm{m}^{3}\right)$

$W:$ 蒸汽ドレーン $\left(\mathrm{m}^{3}\right)$

$R$ ：液回收量（大ガス時の回收含まず） $\left(\mathrm{m}^{3}\right)$ そすれば大ガス開始時に㔚ける L.S. 濃度 $B(\mathrm{~g} / \mathrm{l})$ は 次式で與えられる：

$$
B=\frac{L}{C w+A+W-R}
$$

この中 $L, C w$ 及び $A$ はチップ釜話量によつて變化す る。特に $A$ はチップ釜詰量の如何に拘らず常に木釜 頂部へ達する迄䢪液される篇チップ充填量の檑減仙よ り減增する。今，標潐釜詰量 $C$ (石)，釜詰量の變動 
俰數を $a$ (但し標準の昜合を 1 とする)，木金容積を $D\left(\mathrm{~m}^{3}\right)$ とすれば,

$\frac{D}{C}$ : 標準狀態でチップ 1 石が木釜內で占める容積, $\frac{D}{C} \times C$ ：標準狀熊で仕込チップ全量が木釜內で占 める容積,

$\frac{D}{C} \times a C$ : 任意の釜詰チップ量が木釜內で占める 全容積, (但し $a=\frac{C^{\prime}}{C}: C^{\prime}$ は任意の狀態の チップ公詰量)

なる故, 釜詰量變化による添液量の增減量 $F\left(\mathrm{~m}^{3}\right)$ は 次式で表わし得る。

$$
F=\frac{D}{C} \times C-\frac{D}{C} \times a C=(1-a) D
$$

實際上蒸氣ドレーンと液回收量にも變動あろらが絕 對値が不明でしかも兩者共にチップ金詰量の變化に比 して小さいと考えられる故繁雜を避ける舃に一隹一定 として

$$
W-R=K \text { ( =一定) }
$$

とするとチップ金詰量の乿化を考虑した L.S. 濃度は

$$
B=\frac{a L}{a C w+\{A+(1-a) D\}+K}
$$

なる式で與えられる。ここで

$$
\begin{aligned}
& C w=14.2 \mathrm{~m}^{3} \\
& A=4,000 \mathrm{cf}=113.0 \mathrm{~m}^{3} \\
& W=48,000 l b s=22.0 \text { 雨 }=22.0 \mathrm{~m}^{3} \text { (本均) } \\
& R=1,600 \mathrm{cf}=45.3 \mathrm{~m}^{3} \\
& \therefore K=W-R=-23.3 \mathrm{~m}^{3} \\
& D=5,620 \mathrm{cf}=159.5 \mathrm{~m}^{3} \\
& a=1 \text { の場合, イージー蒸解で } B=70 \mathrm{~g} / 1 \text { と }
\end{aligned}
$$

すれば

$$
L=7,270 \mathrm{~kg}
$$

從つてイージーの場合

$$
B=\frac{7270 a}{249.2-145.3 a} \quad(\text { イージー) }
$$

同樣にストロングの場合

$$
\left.B^{\prime}=\frac{6250 a}{249.2-145.3 a} \quad \text { (ストロング }\right)
$$

そなる。この2式より算出してチップ金詰量の戀動に 件う L.S. 濃度の變化を示せ梳第 1 表の如くである。

普通操業に颃いてチップ金詰量及び送液に土2.5\% 位の變動が常にもるものとすれば一定蒸解度のパルプ を得る場合で廃液中の L.S. 濃度に就いてはイージ ーでは 74.3〜 65.8 g/l，ストロングでは $64.0 \sim 56.6 \mathrm{~g} / \mathrm{l}$ の閒で變動がある譯である。ここで蒸解の過不足によ るパルプ蒸解度の變化 (郎ち L.S. 量變化) を考慮し て $\pm 2.5 \%$ 變動範圍を第 4，及び第5 凅(それぞれ イージー及びストロング蒸解の場合) 上に求めれば破 線に示す如くになり，この範圍に收まる割合はイージ ーて $85.5 \%$ ，ストロングて $85.0 \%$ でる。この場合 L.S. 量を正確にイージー $70 \mathrm{~g} / 1$, ストロング $60 \mathrm{~g} / \mathrm{l}$
迄蒸解した時にはイージー组率 17 23, ストロング 㹂素價 8.9〜11.1 の間のパルプが得られる。

$70 \mathrm{~g} / 1$ 或いは $60 \mathrm{~g} / 1$ まで蒸解して確實に許容變動 範圍內にある蒸解度のバルプが得られる精度は 範園 $\frac{\text { 內に入るサンプル數 }}{\text { 總サンプル數 }}=75 \%$ となる（但し晒萃及び留 素價の測定㛊差をそれどれ土1\%及び さ0.5\%と見て 考虑した)。

5. 本法と他の蒸解終點判定法との比較 從來蒸解終墨の判定に比色法と妍用され, 蒸解の進

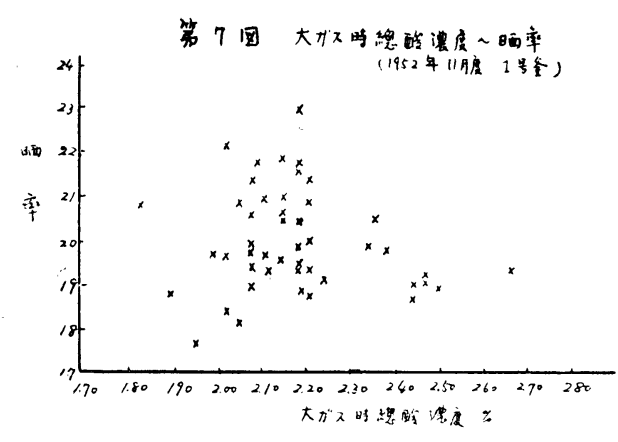

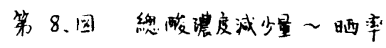

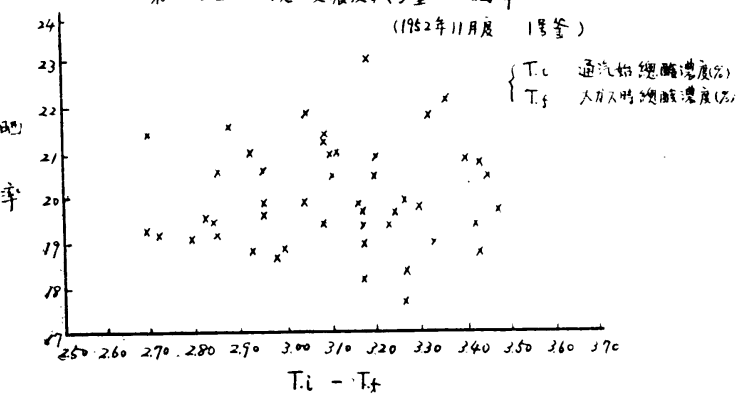

行度を一應數字的に表わす Winkler 法に依る殘酸濃 度と蒸解度との關係を檢討して見た。郎ち第 7 圖及び 第 8 圖は同一木釜に拈ける 1 カ月分の 47 釜に就いてこ の關係をプロットしたものである。この圖より明らか な如く兩者の間には殆んど相關關係は認められない。

比色法に至つては比色計を使用しない限り蒸解進行． 過程を數的に表示することは不可能で, 假りに數的に 表わし得たとしても條件の變化により色相に變動を來 すのでこれに依存する事は困難である。

かかる現狀に括いて L.S. 溶出量測定に依る蒸解終 點制定法か $75 \%$ の精度で蒸解終點を數的に規定出來る ことは一大進步といつても過言ではない。

\section{IV 䆩際操業に本法を適用した場合に就いて}

上記の實驗結果を基礎にして昭和 28 年 3 月より本法 を實際操業に探用し蒸解終點決定の資料として居る。

しかしながら實際操業に扣いては前述の如く常に種 種の蒸解佟件にある範圍の變動があると考えられるの で本法の適應性を簡單に批制することは早計であるが， 一㤫本法探用前後の蒸解度の變動を纆めて見るとスト ロング及びイージー蒸解の場合にそれぞれ第 2 及び第 
3 表の如くKなる。この結果より兩者共本法探用後の 蒸解度の變動範赭は縮少, 欧善された結果が得られ, 本法の適恳性が認められる。

第 2 表 ストロング蒸解の場合

\begin{tabular}{|c|c|c|c|}
\hline L.S. 定量 & 探用前 & 探 & 後 \\
\hline 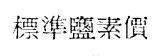 & 10.5 & & 10,5 \\
\hline 蒸解回教 & 50 & & 50 \\
\hline & 監菜價 & 置菜價 & $\begin{array}{l}\text { 䈝液中 } \\
\text { L.S.量 } \mathrm{g} / \mathrm{l}\end{array}$ \\
\hline 最 & 12.53 & 11.83 & 59 \\
\hline 最 & 8.40 & 9.25 & 51 \\
\hline 本 & 10.49 & 10.49 & 53.61 \\
\hline 籍 & 4.13 & 2.58 & 8 \\
\hline 標倠偏差 & 0.778 & 0.573 & - \\
\hline
\end{tabular}

第 3 表 イージー蒸解の場合

\begin{tabular}{|c|c|c|c|}
\hline L.S. 定量 & 探用前 & 採 & 後 \\
\hline 㯲準哂率 & 20 & & 29 \\
\hline 蒸解回數 & 50 & & 19 \\
\hline & 唒率 & 唒奕 & $\begin{array}{l}\text { 廢落中の } \\
\text { L.S.量 } \mathrm{g} / 1\end{array}$ \\
\hline 最 & 22.7 & 22.2 & 74 \\
\hline 最 & 17.2 & 17.8 & 65 \\
\hline 平 & 20.01 & 19.88 & 69.18 \\
\hline 笨 & 5.5 & 4.4 & 9 \\
\hline 標準偄差 & 1.143 & 0.974 & - \\
\hline
\end{tabular}

\section{$\mathrm{V}$ 總 括}

以上の結果を總括すれば次の如くである。

1. イージー及びストロング蒸解に抋いて，大ガス 開始時の廢液の L.S. 濃度がそれぞれ70及び $60 \mathrm{~g} / 1$ に 達すれば75\%の精度て許容變動範圈內にある蒸解度
(イージー晒杽 19〜20，ストロング警素價 9.5 11.0) のバルプが得られる。但しこの L.S. 濃度は當然各工 場每の種々な操業條件の㡩化によつて異ると考学るべ きである。

2. 休日における $100^{\circ} \mathrm{C}$ 止め釜の場合も L.S. 量に よつて蒸解條件をある程度規正し得る。

3. L.S.定量法を蒸解の終點判定に用いる場合には 蒸解の末期に適當な時閒間隔を置いて L.S. 量を測定 し, 希望の L.S. 量に達した時大ガスに移ればよい。 1 回の測定時間は5〜6分である。

4. 察際操業に本法を採用した結果では，末げ檢討 の餘地はあるが蒸解度の變動範圍が探用前より縮少さ れた點から見てその適應性が認められる。

5. 乙かしながら本法のみて蒸解の終默決定を行う ことは早計である。郎ち分析法の精度, 熟練度, 個人 䛠差等及び藥液組成, 迼液量, チップ釜詰量, 樹種の 戀化又は混合萃等と L.S. 濃度との關係を檢討した後, これらの諸條件を䟺案して終點㳉定を行わなければな らない。

終りに本寞䑪に當り種々御指導下された九大, 千手 諒一博士に樑謝致す次第である。(28.8.22. 受付)

（䨘驗擔當者 高山 哲）

\section{參考交献}

(1) Patterson, R. F.: 他 4 名: Pulp Paper Mag. Can. 52, 12. 105 111 (Nov. 1951)

(2) 千手諒一: バルプ及び工業雜誌，Vol. 6.p. 480 $\sim 487$ (1952) No. 7

(3) 千手諒一: バルブ及び紙工業猚誌, Vol. 7.p. $166 \sim 170$ (1953) No. 3

(4) 北川，田中: 製紙技術 (九州製紙工業會) 昭27 年 7 月 No. 4. p. 8 9

(5) R. Senju: Bull. Chem. Soc. Japan, 25, 131, (1952)

(6) Tappi Standard T-214m-37

(7) E. Hägglund: Papier Fabr., 24, 449, 483 (19 26) 